Vol. 22, $n^{\circ} 1 \mid 2018$

Varia

\title{
Élisabeth Lusset, Crime, châtiment et grâce dans les monastères au Moyen Âge (XII ${ }^{e}-\mathrm{XV}^{e} \mathrm{~s}$.)
}

Turnhout: Brepols, 2017406 p., ISBN: 978-2-503-56765-5

\section{Guy Geltner}

\section{(2) OpenEdition}

\section{Journals}

Electronic version

URL: http://journals.openedition.org/chs/2168

DOI: $10.4000 /$ chs. 2168

ISSN: 1663-4837

\section{Publisher}

Librairie Droz

Printed version

Date of publication: 31 October 2018

Number of pages: 135-137

ISSN: $1422-0857$

\section{Electronic reference}

Guy Geltner, "Élisabeth Lusset, Crime, châtiment et grâce dans les monastères au Moyen Âge (XIIe-XVe s.)", Crime, Histoire \& Sociétés / Crime, History \& Societies [Online], Vol. 22, n | 2018, Online since 31

December 2018, connection on 13 January 2021. URL: http://journals.openedition.org/chs/2168 ; DOI: https://doi.org/10.4000/chs.2168

This text was automatically generated on 13 January 2021.

(c) Droz 


\section{Élisabeth Lusset, Crime, châtiment et grâce dans les monastères au Moyen Âge (XII ${ }^{e}-X V^{e}$ s.)}

Turnhout: Brepols, 2017406 p., ISBN: 978-2-503-56765-5

\section{Guy Geltner}

\section{REFERENCES}

Élisabeth Lusset, Crime, châtiment et grâce dans les monastères au Moyen Âge (XII ${ }^{e}-\mathrm{XV}^{e} \mathrm{~s}$.). Turnhout: Brepols, 2017406 p., ISBN: 978-2-503-56765-5

1 Élisabeth Lusset's wide-ranging and lucid study of monastic crime, punishment and absolution has much to recommend it to this journal's readership. Although the book is predominantly a contribution to the history of monastic social and legal history, it marshals abundant evidence regarding deviancy and situates cloistered life within its broader and ever-changing social and cultural contexts, thereby challenging a traditional approach to convents as (proto-)total institutions. Lusset convincingly shows how monks and nuns, in bringing about social disequilibrium, were both cognizant of external audiences and influenced by values, such as pride and honor, ties to kin, and an enduring fear of scandal, all of which they shared with society at large. What is more, the normative boundaries and the very processes by which offenders were denounced, tried, punished and absolved, took part in parallel developments in the fields of ecclesiastical and lay criminal justice, and the place these occupied in broader political negotiations.

Building on and moving beyond local case studies, the book examines some 1266 violations (some in the form of charges, others outright confessions) culled from an impressive range of sources across western Europe between the twelfth and fifteenth century. In this large sample, members of the Cistercian and Cluniac orders are prominent (508 cases collectively), as are religious men and women who fell under the 
diocesan justice systems of England and Normandy (144). However, the largest "group" of deviants is far more heterogenous in their location and affiliation and emerges from the registers of the papal chancellery and especially the papal penitentiary (526 collectively), highly centralized organs that adjudicated, punished and absolved in diverse contexts. The methodological challenges of assembling the dataset and analysing it are presented very clearly in chapter one, before the author moves on to survey the evolving legal procedure underlying monastic criminal justice in chapter two.

3 The early medieval Rule of St. Benedict, and texts inspired by it, encouraged monks and nuns to denounce their coreligionists' transgressions as part of their own path to salvation and instructed superiors to deal with deviants in a gradual, individual manner. Yet the dynamics of criminal discovery as well as punishment showed signs of deep change in later centuries, eroding individual convents' autonomy along with its priors' capacity to discern their underlings' spirits and settle their disputes. A conspicuous factor here was the increasing popularity of centralized monastic orders (Cistercians, Carthusians, etc.), which in their quest to take control out of local bishops' hands also reduced abbots' traditional powers. Lusset traces the process by which routine visitations of an order's affiliated houses expanded general chapters' prerogatives and solidified the papacy's direct control over the monastic world. This short-circuiting of the church's theoretical hierarchy bolstered centralized, top-down inquests at the expense of local, bottom-up procedures. Although very few full protocols of these processes have come down to us, Lusset avers that external jurisdictions absorbed a growing part of the criminal procedure's workflow, including punishment and pardon, dealt with in later chapters.

The profile of late medieval monastic deviance is sketched in chapter three. The author provides a compound picture and limits herself here to what she and the sources construe as major crimes, offenses that would have resonated as such also beyond the cloister: verbal and physical violence, homicide, theft, forgery, arson and sorcery. By contrast, sexual incontinence and minor acts of disobedience towards one's superior are deliberately set aside, although Lusset is careful to remind us that these very much defined monastic deviance on a regular basis, as did the grave act of apostasy, that is leaving one's cloister unauthorized. The book's broader historiographical intervention is also well served here by a sensitive spatial analysis of crimes' location, which reinforces the sacred topography of the cloister, on the one hand, and shores up sisters' and brethren's awareness of an external gaze which helped shape how and where they perpetrated their acts, on the other. A final material element straddling the religious and secular worlds are the offensive weapons sometimes used by monks in violent crimes, tools that in theory should have had little room in any convent.

Chapter four moves beyond the spatial and material realms to those of emotions and politics, once again underscoring the unique profile of religious misbehaviour without losing sight of its relationship with society at large. Lusset vividly illustrates the key role played by emotions such as envy, fear, hatred and greed, identity markers such as age, ethnicity and socioeconomic status, and forces such as family affinity in power struggles within the cloister, conflicts that could culminate in major crimes. On the other hand, she underscores how texts reporting deviance nod at both lay and ecclesiastical expectations from the monastic life, including as a Christian paradigm of perfection and as an engine of personal and universal spiritual reform. Chapter five 
zooms in on the social realities of punishments and their goals, pitting correction against a desire to avoid public scandal as the major tension operating behind judges' decision making. The chapter charts a broad (but not linear) transition in the later Middle Ages from external exile (excommunication) to an internal one (incarceration), sometimes even in centralized facilities developed by an order. Two factors are at play here which have much to do with the non-monastic world, namely the centralization of power above the cloister level and the growing fear of scandal besetting the church in general. Both, as the book repeatedly stresses, meant a real decline in abbots' and abbesses' decision-making power.

6 Chapter six deals, albeit tangentially, with what is perhaps the most unique challenge of the monastic (and ecclesiastical) criminal justice procedure in the later Middle Ages, namely mitigating between private and public agendas. As such, it chimes in with debates in the lay world about the goal of punishment that took place well before Beccaria. The abbot, the order's master general, the bishop and especially the pope were charged with guiding their flocks towards individual salvation, a demanding task that could run counter to the creation of amenable social conditions for doing so at the group level. The strong pressure to allow offending monks to reintegrate, for instance, was laudable from the individual's perspective, but it could chafe at a community's sense of identity and solidarity, especially when the original violation was perceived to have created a great deal of instability. The orders' general chapter meetings' and the papal penitentiary's ability in particular to insinuate themselves into the final phase of the criminal procedure, which is Lusset's focus in this chapter, thus risked antagonizing local communities. It is small wonder that general chapter rulings were at times ignored, and that popes' mitigation of punishment and full absolutions could come under sharp criticism and even violent resistance on the part of individual monasteries.

7 The strands connecting this fine book's observations to broader social and legal processes differ in their visibility across sections and chapters, but they nonetheless prepare the ground for further integration of this unique, if too often essentialized, world into scholarship on crime and punishment. Given their wealth, especially in a premodern context, Lusset's findings will surely benefit from a more explicit engagement in criminal and penal statistics, as they would from plotting violations more systematically against events in the life of a monastery (patronage, endowments and even elections, which Lusset already alludes to as a potential destabilizer), a monastic order (status, privileges, etc.) and a region (war, famine), as well as general elements such as seasonality or a transregional calamity such as plague. Broadening the scope of monastic deviance to cover the numerous and fairly well-documented mendicant orders of the period could provide another avenue, one that has the added benefit of sharing an urban social context already studied by scholars of lay crime and punishment. Last but not least, building on this book's important observations on female religious deviants can enrich debates on the history of gender and crime, as could its insights about offenses among monks to the history of sexuality, crime and identity.

8 The latter suggestions do not detract from the achievement of this stimulating and thorough piece of scholarship. In the goals that it has set itself, and which are roundly accomplished, it will benefit many historians of crime and punishment. 


\section{AUTHORS}

\section{GUY GELTNER}

Universiteit van Amsterdam

g.geltner[at]uva.nl 